\title{
Expression of ESR1 in Glutamatergic and GABAergic Neurons Is Essential for Normal Puberty Onset, Estrogen Feedback, and Fertility in Female Mice
}

\author{
Rachel Y. Cheong, ${ }^{\star}$ Katja Czieselsky, ${ }^{\star}$ Robert Porteous, and ${ }^{\circledR}$ Allan E. Herbison \\ Centre for Neuroendocrinology and Department of Physiology, School of Medical Sciences, University of Otago, Dunedin 9054, New Zealand
}

Circulating estradiol exerts a profound influence on the activity of the gonadotropin-releasing hormone (GnRH) neuronal network controlling fertility. Using genetic strategies enabling neuron-specific deletion of estrogen receptor $\alpha$ (Esr1), we examine here whether estradiol-modulated GABA and glutamate transmission are critical for the functioning of the GnRH neuron network in the female mouse. Using Vgat- and Vglut2-ires-Cre knock-in mice and ESR1 immunohistochemistry, we demonstrate that subpopulations of GABA and glutamate neurons throughout the limbic forebrain express ESR1, with ESR1-GABAergic neurons being more widespread and numerous than ESR1-glutamatergic neurons. We crossed Vgat- and Vglut2-ires-Cre mice with an Esr1 ${ }^{\text {lox/lox }}$ line to generate animals with GABAneuron-specific or glutamate-neuron-specific deletion of Esr1. Vgat-ires-Cre;Esr $1^{\text {lox/lox }}$ mice were infertile, with abnormal estrous cycles, and exhibited a complete failure of the estrogen positive feedback mechanism responsible for the preovulatory GnRH surge. However, puberty onset and estrogen negative feedback were normal. Vglut2-ires-Cre; $E s r 1^{\text {lox/lox }}$ mice were also infertile but displayed a wider range of deficits, including advanced puberty onset, abnormal negative feedback, and abolished positive feedback. Whereas $<25 \%$ of preoptic kisspeptin neurons expressed Cre in Vgat- and Vglut2-ires-Cre lines, $\sim 70 \%$ of arcuate kisspeptin neurons were targeted in Vglut2-iresCre;Esr $1^{\text {lox/lox }}$ mice, possibly contributing to their advanced puberty phenotype. These observations show that, unexpectedly, ESR1GABA neurons are only essential for the positive feedback mechanism. In contrast, we reveal the key importance of ESR1 in glutamatergic neurons for multiple estrogen feedback loops within the GnRH neuronal network required for fertility in the female mouse.

Key words: estradiol; GABA; glutamate; GnRH

Significance Statement

Circulating estradiol acts upon the brain to regulate the functioning of many neuronal networks, including those controlling reproduction. Acting in classic homeostatic negative or positive feedback modes, estradiol variably suppresses or enhances the activity of the gonadotropin-releasing hormone $(\mathrm{GnRH})$ neurons throughout the ovarian cycle. We show here that estrogen receptor $\alpha$ (ESR1) within glutamate (VGLUT2) neurons is essential for both the negative and positive estradiol feedback loops. In contrast, ESR1 in GABA neurons is only required for estradiol positive feedback. These studies emphasize the importance of estradiol-modulated amino-acidergic neurons within the GnRH neuronal network and highlight an unexpected prominent role for ESR1-expressing glutamate neurons in fertility control.

\section{Introduction}

Fertility is critically dependent upon estradiol feedback loops involving the brain that ultimately regulate the activity of the gonadotropin-releasing hormone $(\mathrm{GnRH})$ neurons. Evidence gathered over recent years has demonstrated that estrogen receptor $\alpha$ (ESR1) is the key receptor mediating these feedback loops

\footnotetext{
Received May 7, 2015; revised Sept. 4, 2015; accepted Sept. 16, 2015.

Author contributions: A.E.H. designed research; R.Y.C., K.C., and R.P. performed research; R.Y.C., K.C., and A.E.H. analyzed data; A.E.H. wrote the paper.

This work was supported by the New Zealand Health Research Council. We thank Brad Lowell (Beth Israel Deaconess Medical Center) and A.F. Parlow (National Hormone and Peptide Program) for contributing valuable reagents and Rebecca Campbell and Jenny Clarkson for commenting on the manuscript.
}

(Couse et al., 2003; Wintermantel et al., 2006; Glidewell-Kenney et al., 2007; Cheong et al., 2014; Yeo and Herbison, 2014). Because GnRH neurons do not themselves express ESR1 (Herbison and Pape, 2001), considerable effort has been focused upon delineating the ESR1-expressing cell types within the network con-

${ }^{*}$ R.Y.C. and K.C. contributed equally to this work.

Correspondence should be addressed to Prof. Allan E. Herbison, Centre for Neuroendocrinology, Department of Physiology, University of Otago School of Medical Sciences, P.0. Box 913, Dunedin, New Zealand. E-mail: allan.herbison@otago.ac.nz.

R.Y. Cheong's present address: Department of Experimental Medical Science, Lund University, Sweden.

DOI:10.1523/JNEUROSCI.1776-15.2015

Copyright $\odot 2015$ the authors $\quad 0270-6474 / 15 / 3514533-11 \$ 15.00 / 0$ 
trolling the activity of GnRH neurons (Petersen et al., 2003; Moenter et al., 2009; Prevot et al., 2010; Herbison, 2015).

Elucidating the estradiol-sensitive elements of the GnRH neuronal network has been complicated by the existence of two fundamentally different feedback loops that generate negative and positive feedback. Whereas negative feedback is persistent in both males and females and restrains GnRH neuron activity, positive feedback only exists in females and occurs exclusively at the midpoint of the ovarian cycle to generate the preovulatory $\mathrm{GnRH}$ surge, leading to ovulation (Levine, 2014; Herbison, 2015). At present, it is believed that different estradiol-sensitive neuronal pathways within the GnRH neuronal network are responsible for positive and negative feedback (Herbison, 2015).

Although retrograde tract-tracing studies in mice have demonstrated that the vast majority of ESR1-expressing primary afferents to the GnRH neurons reside in the periventricular regions of the hypothalamus (Wintermantel et al., 2006), the neurochemical identity of these neurons has not yet been deciphered. Studies over the last decade have focused intensely, if not exclusively, upon the roles of ESR1-expressing kisspeptin neurons in these feedback loops. Whereas a strong case can been made for ESR1-expressing kisspeptin neurons located in the rostral periventricular area of the third ventricle (RP3V) to be involved in the positive feedback mechanism (Clarkson and Herbison, 2009; Ohkura et al., 2009; Smith, 2013), the roles of ESR1-positive kisspeptin neurons in the arcuate nucleus (ARN) remain unclear (de Croft et al., 2012; Dubois et al., 2015).

As has happened for kisspeptin and, more recently, RFamide-related peptides (Khan and Kauffman, 2012), every new neurotransmitter identified within the GnRH neuronal network has been implicated as being involved in the estradiol feedback loops (Kalra, 1993; Kordon et al., 1994; Herbison, 1998). However, the longest and arguably strongest legacy for involvement in estradiol feedback belongs to the amino acid transmitters GABA and glutamate (Herbison, 1998; Petersen et al., 2003; Moenter et al., 2009; Herbison, 2015). All GnRH neurons receive substantial GABAergic and glutamatergic input (Iremonger et al., 2010; Herbison and Moenter, 2011) and manipulations of either amino acid within the brain can modify both the positive and negative feedback mechanisms (Herbison, 1998). However, amino acid neurotransmission is a fundamental element of network functioning in all neuronal circuits (Foster and Kemp, 2006). Therefore, it has been impossible experimentally to decipher the impact and roles of estradiol-modulated activity from that of more general ongoing GABA/glutamate neurotransmission within neuronal circuits in vivo.

To address this issue, we have used here cell-specific gene targeting strategies to delete ESR1 from either all GABAergic or all VGLUT2-expressing (glutamatergic) neurons in mice. We report that ESR1 in these neurons is indeed critical for the normal functioning of the GnRH neuronal network and fertility with ablation from GABA or glutamate neurons having unexpected, differential effects on the various estradiol feedback loops found in peripubertal and adult mice.

\section{Materials and Methods}

\section{Experimental animals}

Vgat-ires-Cre knock-in (Vong et al., 2011) and Vglut2-ires-Cre knock-in (Vong et al., 2011) mouse lines were used. VGLUT2 is the glutamate transporter used by all glutamatergic neurons in the hypothalamus, thalamus, midbrain, and hindbrain (Takamori, 2006), whereas all GABAer- gic neurons express VGAT (Wojcik et al., 2006). Both the Vgat-ires-Cre and Vglut2-ires-Cre knock-in mouse lines have been fully characterized and shown to express Cre selectively in GABAergic and glutamatergic neurons, respectively (Vong et al., 2011). To fluorescently label GABAergic and glutamatergic neurons, the different Cre driver lines were crossed with the Ai9 Cre-dependent tdTomato reporter (Madisen et al., 2010). To delete ESR1 from all GABA or VGLUT2 neurons, the different Cre driver lines were crossed with Esr $1^{\text {lox/lox }}$ mice (Wintermantel et al., 2006). Mice were genotyped by PCR. All mice were housed either with their dam [for mice $<$ postnatal day 21 (P21)] or in cages of 3-4 animals under $12 \mathrm{~h}$ light/dark cycles (lights on $06: 00 \mathrm{~h}$ ) with ad libitum access to food (Irradiated Rat and Mouse Diet, 4\% fat, product \#12152; Specialty Feeds) and water. All procedures were approved by the University of Otago Welfare and Ethics Committee.

Assessment of puberty, estrous cyclicity, and estrogen feedback Vgat/Vglut2-ires-Cre;Esr $1^{\text {lox/lox }}$ mice and littermate Esr $1^{\text {lox/lox }}$ controls were weaned at P21 and checked daily for vaginal opening and subsequently for first estrus by daily vaginal smear. At 3-4 months of age, estrous cyclicity was assessed by undertaking morning vaginal smears for a period of $26 \mathrm{~d}$. Cyclicity was determined by counting the number of full cycles between proestrous smears occurring over this time. Days per cycle were determined by counting the numbers of days between consecutive proestrous smears and the percentage of time spent in estrous was assessed by determining the percentage of days with smears dominated by cornified epithelial cells (estrus). Fecundity was assessed in a separate group of mice by mating knock-out and age-matched control (Vgat/ Vglut2-ires-Cre ${ }^{+1-}$ mice) male and female mice with wild-type mates for 3 months. The numbers of litters and pups per litter were counted for each dam.

To test the patency of the negative and positive feedback mechanisms, adult Vgat/Vglut2-ires-Cre;Esr $1^{\text {lox/lox }}$ mice and littermate controls $(>60$ $\mathrm{d}$ of age) received ovariectomy (OVX) and were treated with $17-\beta$ estradiol (E2). For negative feedback, mice were anesthetized with $1.5 \%$ halothane, a tail blood sample taken, and OVX performed. Two to 3 weeks later, mice were reanesthetized, a blood sample taken to assess OVX levels of luteinizing hormone (LH), and an E2-filled SILASTIC capsule ( $1 \mu \mathrm{g}$ E2/20 g body weight, s.c.) implanted as reported previously (Yeo and Herbison, 2014). Five days later, a submandibular vein blood sample was obtained to assess the ability of E2 to chronically suppress LH secretion. The estrogen positive feedback mechanism was assessed using an established protocol (Wintermantel et al., 2006) in which OVX mice were implanted with an E2-filled SILASTIC capsule (as above) and $6 \mathrm{~d}$ later given estradiol benzoate ( $1 \mu \mathrm{g}$ of estradiol $/ 20 \mathrm{~g}$ body weight, s.c.) at 09:00 $\mathrm{h}$ and killed the following day with an overdose of pentobarbital (3 $\mathrm{mg} / 100 \mu \mathrm{l}$, i.p.) between 17:30 and 19:00 h, with a final blood sample taken from the right atrium and the mouse being perfused with paraformaldehyde.

Plasma LH concentrations were determined in duplicate by radioimmunoassay using the anti-rLH-S-11 antiserum and $\mathrm{mLH}-\mathrm{RP}$ reference provided by A.F. Parlow (National Hormone and Peptide Program, Torrance, California). Assay sensitivity was $0.2 \mathrm{ng} / \mathrm{ml}$. The intraassay coefficient of variation was $4.6 \%$.

\section{Immunohistochemistry}

Mice were anesthetized with pentobarbital and perfused transcardially with $15 \mathrm{ml}$ of $4 \%$ paraformaldehyde in PBS. Brains were removed, postfixed at room temperature for $1 \mathrm{~h}$, and placed in 30\% sucrose solution overnight. The following day, three sets of $30-\mu \mathrm{m}$-thick coronal brain sections were cut on a freezing microtome from each brain for subsequent free-floating immunohistochemistry.

ESR1 immunohistochemistry. Single-label peroxidase-based staining was undertaken on one set (1:3) of coronal brain sections extending from the medial septum through to the caudal hypothalamus from Vgat/Vglut2-ires-Cre;Esr $1^{\text {lox/lox }}$ mice and controls. Sections were incubated for $48 \mathrm{~h}$ at $4^{\circ} \mathrm{C}$ in a well characterized rabbit polyclonal primary antisera directed against ESR 1 (1:10,000, Millipore, catalog \#06-935; Cheong et al., 2014) in Tris-buffered saline (TBS) containing $0.3 \%$ Triton $\mathrm{X}-100$ and $0.25 \%$ BSA and $2 \%$ normal goat serum. 
Sections were then incubated in biotinylated goat anti-rabbit immunoglobulins (1:200; Vector Laboratories) for $90 \mathrm{~min}$ at room temperature. After subsequent washing in TBS, the sections were incubated in Vector Elite avidin-peroxidase (Vector Laboratories) at 1:100 for $90 \mathrm{~min}$ at room temperature. Immunoreactivity was revealed using glucose-oxidase, nickel-enhanced diaminobenzidine hydrochloride $(\mathrm{DAB})$ that resulted in a black precipitate within the nucleus of the labeled cell. Dual-label immunofluorescence staining was undertaken on coronal sections taken throughout the forebrain of female diestrous Vgat/Vglut2-ires-Cre;lox-tdTomato mice using the same ESR1 antisera at 1:5000 dilution, followed by 1:400 biotinylated goat antirabbit immunoglobulins and streptavidin Alexa Fluor 488 conjugate (1:400, catalog \#S11223; Life Technologies). Dual-labeled cells exhibited green fluorescent nuclei and the endogenous red tomato fluorescence in the cytoplasm.

GnRH-cFOS immunohistochemistry. Dual-label DAB immunostaining was undertaken as reported previously (Clarkson et al., 2008). In brief, one set of preoptic area sections from Vgat/Vglut2-ires-Cre; Esr $1^{\text {lox/lox }}$ mice and controls was incubated in a rabbit polyclonal primary antisera directed against cFOS (1:8000; SC52; Santa Cruz Biotechnology) for $48 \mathrm{~h}$ at $4^{\circ} \mathrm{C}$, followed by 1:200 biotinylated antirabbit immunoglobulins and 1:100 Vector Elite avidin-peroxidase, and immunoreactivity was revealed using nickel-enhanced DAB. Sections were then processed for GnRH by incubation in a rabbit polyclonal primary antisera directed against GnRH (LR5 1:20,000; gift from R. Benoit, Montreal) for $48 \mathrm{~h}$ at $4^{\circ} \mathrm{C}$ and visualized using the same combination of reagents with the exception that $\mathrm{DAB}$ was used without nickel.

Kisspeptin immunohistochemistry. To determine the degree to which Cre was expressed in kisspeptin neurons in Vgat-ires-Cre and Vglut2ires-Cre mice, one set of sections taken throughout the hypothalamus of diestrous female Vgat and Vglut2-ires-Cre mice was incubated with a well characterized polyclonal rabbit antisera directed against Cre (1:1000; gift of G. Scheutz, Heidelberg; Casanova et al., 2001) using the same protocol described above for ESR1 nickel-DAB immunohistochemistry. This was followed by immunostaining with a polyclonal rabbit antisera directed against kisspeptin (1:10,000; AC566; gift of A. Caraty, Nouzilly; Clarkson et al., 2009) and processed using DAB only as a chromagen.

\section{Immunohistochemical analysis}

ESR1 expression in Vgat/Vglut2-ires-Cre;lox-tdTomato mice. An analysis of the distribution and density of ESR1-positive GABA and glutamatergic neurons in the adult female mouse forebrain was undertaken by mapping the locations of dual labeled cells (one dot per 10 duallabeled cells with ESR1-positive green nuclei and cytoplasmic tomato fluorescence) onto the Franklin and Paxinos brain atlas (Franklin and Paxinos, 1997). A quantitative analysis of ESR1 expression in GABA neurons was undertaken in the anteroventral periventricular nucleus (AVPV; plates 28-29), ARN ( plates 45-47), caudal medial preoptic nucleus (cMPN; plates 32-33) and posterodorsal medial amgydala (MEApd; plates 45-46). Analysis of ESR1 expression in VGLUT2 neurons was undertaken in the AVPV, ARN and posteroventral medial amygdala (MEApv; plates 45-47). Both sides of the brains were photographed using a Zeiss LSM 710 confocal laser scanning microscope with Zeiss ZEN 2009 software. Image stacks were acquired at 3 $\mu \mathrm{m}$ intervals with a $20 \times / 0.8$ PlanApo objective and the pinhole was adjusted to 1 air unit. The total number of cells with green fluorescent nuclei alone, endogenous tdTomato fluorescence alone, and both labels, were counted in two optical sections $15 \mu \mathrm{m}$ apart in each image stack using the ImageJ version $1.49 \mathrm{~b}$ Multipoint tool. These values were combined to provide a single value for each section. Two sections were analyzed for each brain region with values combined for each mouse to generate group mean \pm SEM values.

ESR1 analysis in Esr1 knock-out mice and controls. The numbers of ESR1-immunoreactive cells within specific hypothalamic nuclei were determined by counting all nickel-DAB positive nuclei within the AVPV (plates 28-29 of Franklin and Paxinos, 1997), medial preoptic nucleus (MPN; plates 31-32), ventrolateral division of the ventrome- dial hypothalamus (VMHvl; plates 43-47), ARN (plates 45-47), and MEApd (plates 45-47). Two sections from each area were analyzed in every mouse. Each section was photographed and a predefined rectangle (AVPV, MEApd), oval (MPN, VMHvl), or triangle (ARN) "region of interest" overlaid upon the hypothalamic nuclei so that immunoreactive nuclei were counted automatically using the AnalySIS Life Sciences Series program (Soft Imaging System). Analysis was undertaken by an investigator blind to the genotypes of the brain sections and with the thresholding and placement of regions of interest maintained constant throughout the analysis.

GnRH-cFOS analysis in knock-out mice and controls. This was undertaken as described previously (Clarkson et al., 2008). In brief, the GnRH neurons located in the preoptic area (plates 25-27) with and without nuclear nickel-DAB staining were counted per section for each mouse and individual values combined to generate group means.

Vgat/Vglut2-Cre and kisspeptin immunohistochemistry in Vgat-and Vglut2-ires-Cre mice. In each mouse, the number of kisspeptin-immunoreactive cells (brown cytoplasm) with or without Cre (black nuclei) were counted in two sections each containing the RP3V (plates 2932 ) and the ARN (plates 45-47), the two brain regions where kisspeptin neurons are found (Clarkson et al., 2009). Values were combined to provide an average for each animal and grouped to provide mean \pm SEM values and the percentage of kisspeptin neurons with Cre determined.

\section{Statistics}

All data are presented as group means \pm SEM. Repeated blood sampling experiments were analyzed using repeated-measures one- or two-way ANOVA with post hoc Bonferroni tests. For multiple comparisons examining ESR1 deletion across multiple brain regions, the Tukey post hoc test was used. Comparisons between two experimental groups were undertaken with nonparametric Mann-Whitney tests. Statistical analyses were conducted using Prism version 6.0 (GraphPad Software).

\section{Results}

\section{ESR1 is expressed by GABA and glutamate neurons}

\section{throughout the limbic forebrain}

Vgat/Vglut2-ires-Cre mice were crossed onto the Ai9 Credependent tdTomato reporter line to generate Vgat/Vglut2ires-Cre;lox-tdTomato mice and processed for ESR1 immunohistochemistry to determine the locations of ESR1positive GABA and glutamate neurons throughout the forebrain of adult diestrous female mice $(n=4)$. The distribution of VGAT- and VGLUT2- fluorescent tdTomato cells was as reported previously for these mice (Vong et al., 2011). Immunohistochemistry for ESR1 revealed a heterogeneous distribution of cells exhibiting nuclear-located immunoreactivity with nucleolar exclusion (Fig. 1 $A, D$ ) throughout the brain, as noted previously (Mitra et al., 2003). Dual-labeled VGATESR1 (Fig. 1C) and VGLUT2-ESR1 (Fig. 1F) cells were detected throughout the limbic forebrain with a predominantly overlapping distribution (Fig. 2).

VGLUT2-ESR1 cells were detected in the AVPV, medial aspects of the preoptic area, principally the periventricular nucleus (PVpo), ARN (Fig. 1F), and the paraventricular, ventromedial, and dorsomedial nuclei (Fig. 2). Outside of the hypothalamus, dual-labeled cells were detected predominantly within the MEApv (Fig. 2), with small numbers of cells also observed in other divisions of the amygdala, including the anterior and posteromedial cortical amygdaloid nucleus, anterior medial amygdaloid nucleus, and lateral division of central amygdaloid nucleus.

VGAT-ESR1-positive cells were detected in much greater abundance in all of the above brain regions except the MEApv and also in the anterior and posterior compartments of the 
bed nucleus of the stria terminalis, throughout the medial preoptic area, and in the lateral septum and dentate gyrus (Fig. 2). Within the amygdala, dual-labeled cells were concentrated in the MEApd (Fig. 2).

To evaluate the proportions of glutamatergic and GABAergic cells expressing ESR1, cell counts were undertaken in the AVPV and ARN of intact female mice $(n=4), 2$ brain regions implicated in the estradiol modulation of GnRH neuron activity in the mouse (Levine, 2014; Yeo and Herbison, 2014; Herbison, 2015), and also in the cMPN and MEApd (for GABA) and MEApv (for VGLUT2); locations of high-density dual-labeled cells for each transmitter (Fig. 2). For GABA, the highest percentage of GABAergic cells expressing ESR1 was in the AVPV (39\%), followed by the MEApd (26\%), cMPN (19\%), and ARN (14\%; Table 1). For VGLUT2, the highest percentage of glutamate neurons expressing ESR1 was in the ARN and MEApv (both 18\%), followed by the AVPV (10\%; Table 2). When considered as a percentage of the total population of ESR1-expressing cells in these brain regions, GABAergic neurons comprised $37 \%$ of AVPV, $26 \%$ of ARN, $24 \%$ of MEApd, and 12\% of cMPN ESR1-positive cells (Table 1). Glutamate neurons made up between $10 \%$ and $16 \%$ of all ESR1 neurons in the AVPV, ARN, and MEApv (Table 2). Together, these studies show that subpopulations of ESR1 neurons express GABA and glutamate in a heterogeneous manner depending upon brain region.

\section{Deletion of Esr 1 from VGAT- and}

VGLUT2-expressing neurons results in altered ESR1 expression in the brain Peroxidase-based immunohistochemistry for ESR1 was undertaken on brains of Vgatand Vglut2-ires-Cre;Esr $1^{\text {lox/lox }}$ mice used for reproductive profiling. Although the overall distribution of ESR1-positive cells was not altered in Vgat-ires-Cre;Esr $1^{\text {lox/lox }}$ mice $(n=7$; Fig. $3 A, B)$, the numbers of immunoreactive cells were significantly reduced in the AVPV $(40 \%, p<0.01$; Fig. $3 A, B), \operatorname{MPN}(70 \%, p<0.001)$, ARN (57\%, $p<0.001)$, and MEApd $(76 \%, p<0.05)$ compared with Esr $1^{\text {lox/lox }}$ controls $(n=16$; one-way ANOVA $F_{(2,25)}=5.634, p=$ 0.0096; with post hoc Tukey tests for multiple comparisons; Fig. 3E). Because all control mice exhibited completely normal reproductive physiology (see below), they were combined into one group. The numbers of ESR1 cells were not altered in the VMHvl (Fig. 3E).

In Vglut2-ires-Cre;Esr $1^{\text {lox/lox }}$ mice $(n=5)$, both the number and distribution of ESR1-immunoreactive cells were sim-
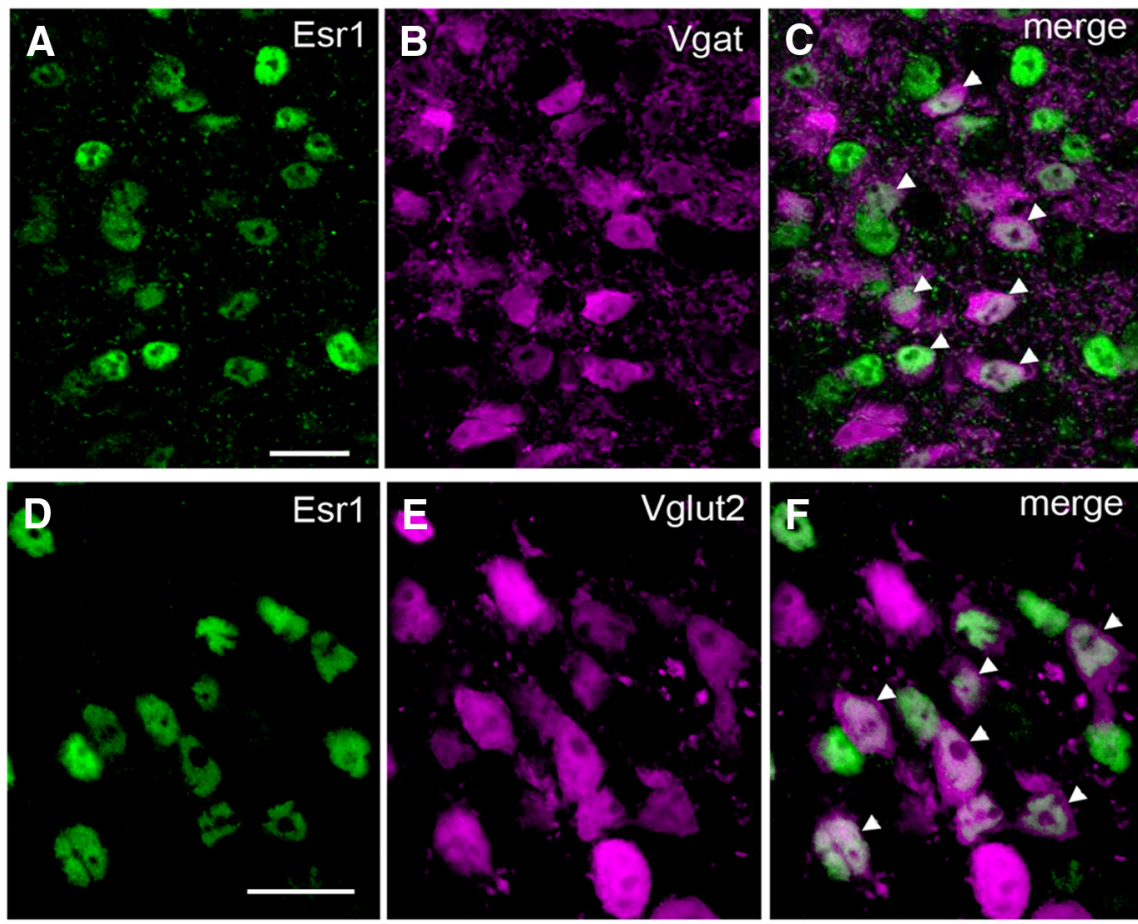

Figure 1. ESR1-expression in GABA and VGLUT2 neurons in the female mouse brain. $\boldsymbol{A}-\boldsymbol{F}$, Dual-label immunohistochemistry for ESR1 (Alexa Fluor 488 green nuclei in $\boldsymbol{A}, \boldsymbol{D}$ ) and VGAT (tdTomato pseudocoloured as magenta, $\boldsymbol{B}$ ) or VGLUT2 (E) from the AVPV and ARN, respectively, of $V$ gat- and Vglut2-ires-Cre mice crossed with a tdTomato reporter. Merged images show individual AVPVVGAT (C) or ARN VGLUT2 (F) neurons expressing ESR1 (white nuclei, arrowheads). Scale bars, $10 \mu \mathrm{m}$.
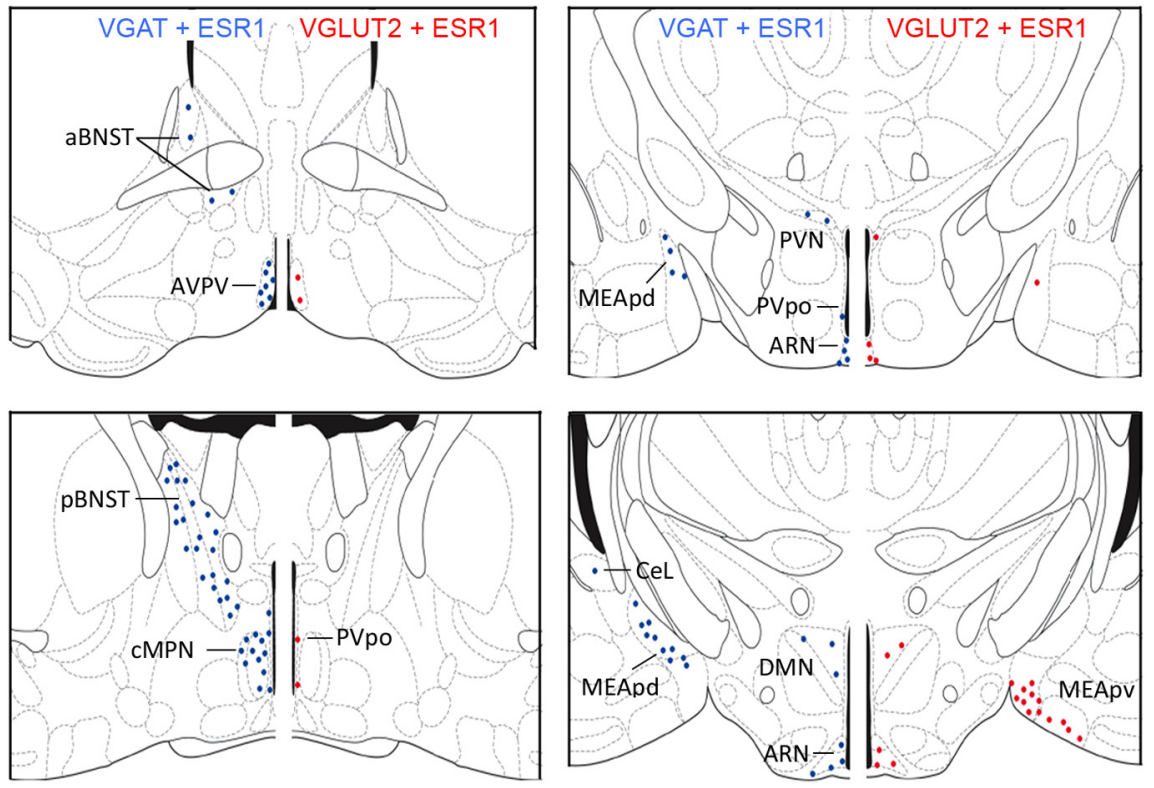

Figure 2. Distribution and density of ESR1-expressing GABA and VGLUT2 neurons in the female mouse brain. Schematic diagrams adapted from Franklin and Paxinos (1997) showing the topography of VGAT-ESR1 (blue) and VGLUT2-ESR1 (red) neurons at four different levels through the female mouse forebrain. Each dot represents 10 dual-labeled cells in a $30-\mu \mathrm{m}$-thick coronal brain section. aBNST, anterior bed nucleus of the stria terminalis; CeL, lateral central amygdala; DMN, dorsomedial nucleus; MEApd, posterior dorsal medial amygdala; MEApv, posterior ventral medial amygdala; pBNST, posterior bed nucleus of the stria terminalis; PVpo, preoptic periventricular nucleus; PVN, paraventricular nucleus.

ilar to that of controls $(n=16)$, with the single exception of the VMHvl, where all ESR1 immunoreactivity was absent $(p<$ 0.001; Fig. 3C-E).

Sections from Vgat-ires-Cre;Esr $1^{\text {lox/lox }}$;tdTomato and Vglut2ires-Cre;Esr $1^{\text {lox/lox}}$; tdTomato mice undergoing immunohisto- 
Table 1. Mean ( \pm SEM) numbers of vGAT- and ESR1-expressing neurons per coronal section in selected areas of the female mouse brain $(n=4)$

\begin{tabular}{|c|c|c|c|c|c|}
\hline Regions & No. of vGAT total & No. of ESR1 cells & No. of dual-labeled cells & \% vGAT cells with ESR1 & $\%$ ESR1 cells with vGAT \\
\hline AVPV & $186.5 \pm 32.4$ & $249.0 \pm 68.5$ & $74.4 \pm 16.4$ & $39.1 \pm 4.3$ & $37.1 \pm 7.4$ \\
\hline ARN & $314.1 \pm 34.5$ & $173.8 \pm 48.1$ & $44.1 \pm 14.5$ & $13.5 \pm 4.0$ & $25.9 \pm 5.5$ \\
\hline CMPN & $527.0 \pm 56.7$ & $911.5 \pm 118.0$ & $101.5 \pm 39.7$ & $19.0 \pm 6.3$ & $12.3 \pm 5.4$ \\
\hline MEApd & $389.5 \pm 23.9$ & $426.0 \pm 56.1$ & $99.3 \pm 15.5$ & $26.3 \pm 5.3$ & $23.7 \pm 3.1$ \\
\hline
\end{tabular}

Table 2. Mean ( \pm SEM) numbers of vGLUT2- and ESR1-expressing neurons per coronal section in selected areas of the female mouse brain $(n=4)$

\begin{tabular}{|c|c|c|c|c|c|}
\hline Regions & No. of vGLUT2 total & No. of ESR1 cells & No. of dual-labeled cells & \% vGLUT2 cells with ESR1 & $\%$ ESR1 cells with vGLUT2 \\
\hline AVPV & $141.1 \pm 17.9$ & $249.0 \pm 68.5$ & $15.4 \pm 6.3$ & $10.0 \pm 3.4$ & $10.3 \pm 4.5$ \\
\hline ARN & $140.6 \pm 10.9$ & $173.8 \pm 48.1$ & $26.6 \pm 6.4$ & $18.3 \pm 2.9$ & $16.9 \pm 3.0$ \\
\hline MEApv & $636.0 \pm 210.8$ & $1157.0 \pm 135.6$ & $130.0 \pm 55.8$ & $18.6 \pm 4.0$ & $10.4 \pm 3.9$ \\
\hline
\end{tabular}



Figure 3. ESR1-expression in Vgat-ires-Cre;Esr $1^{\text {lox/lox }}$ and Vglut2-ires-Cre;Esr $1^{\text {lox/lox }}$ mice. $\boldsymbol{A}, \boldsymbol{B}$, ESR1-immunoreactive nuclei in the AVPV of a female control Vgat-ires-Cre mouse $(\boldsymbol{A})$ and mutant Vgat-ires-Cre;Esr $1^{\text {lox/lox }}$ mouse $(\boldsymbol{B})$. C, $\boldsymbol{D}$, ESR1-immunoreactive nuclei in the mediobasal hypothalamus of a female control Vglut2-ires-Cre mouse $(\boldsymbol{C})$ and mutant Vglut2-ires-Cre;Esr $1^{\text {lox/lox }}$ mouse (D). 3V, Third ventricle. Scale bars, $70 \mu \mathrm{m}$. $\boldsymbol{E}$, Histograms showing mean \pm SEM numbers of ESR1 cells per section in control $(n=16)$, Vgat-ires-Cre;Esr $1^{\text {lox/lox }}(n=7)$, and Vglut2-ires-Cre;Esr $1^{\text {lox/lox }}(n=5)$ mice in 5 different brain regions. ${ }^{* *} p<0.01,{ }^{* * *} p<0.001$ (ANOVA with post hoc Tukey multiple comparison tests). F, G, ESR1 is present in VGLUT2 neurons in control mice (arrowheads, $\boldsymbol{F}$ ) but deleted from ARN VGLUT2 neurons in Vglut2-ires-Cre; Esr $7^{\text {lox/lox }}$,tdTomato mice (G). Scale bar, $5 \mu \mathrm{m}$. chemistry for ESR1 demonstrated a complete absence of ESR1 from all tomato-expressing cells (Fig. $3 F, G$ ).

\section{Deletion of Esr 1 from GABAergic} neurons has no effect on puberty or negative feedback, but abolishes estrogen positive feedback, estrous cyclicity, and fertility

Control mice (Esr1 $1^{\text {lox/lox }}, n=16$ ) exhibited the normal progression of puberty with vaginal opening beginning around P26 (Fig. 4A) and mean (+SEM) vaginal opening occurring on P28.4 \pm 0.6 , with first estrous apparent 3-4 d later at P32.0 \pm 0.9 (Fig. 4B). Vgat-ires-Cre; Esr $1^{\text {lox } / \text { lox }}$ mice $(n=7)$ exhibited similar puberty onset profiles (Fig. 4A,B). Although the cumulative percentage profile for vaginal opening appeared to lag behind that of controls, suggestive of a bimodal distribution, (Fig. 4A), vaginal opening (day $31.0 \pm 1.9$ ) and first estrous (day $34.4 \pm 1.5$ ) were not significantly different from those of controls $[U=35.50$, $p=0.3264$ (vaginal opening) and $U=32$, $p=0.2151$ (first estrous), Mann-Whitney $U$ tests].

Adult control mice $(n=20)$ had $2.9 \pm$ 0.2 complete cycles over the assessment period, with cycles being $7.3 \pm 0.5 \mathrm{~d}$ in duration with $34 \pm 3 \%$ of the time spent in estrous (Fig. 4C-E). Vgat-ires-Cre; Esr $1^{\text {lox } / \text { lox }}$ mice $(n=9)$ exhibited very disordered cyclicity, with only occasional cycles detected $(0.7 \pm 0.4$ cycles; $U=16$, $p<0.001$, Mann-Whitney $U$ test) interspersed among a predominantly $(81 \pm 5 \%)$ estrous smear pattern $(U=$ $0, p<0.001$, Mann-Whitney $U$ test; Fig. $4 C-E)$. Fecundity studies revealed that Vgat-ires-Cre;Esr $1^{\text {lox/lox }}$ mice were infertile, with no litters born to mutant mice $(n=5)$ compared with $4.2 \pm 0.4$ litters to Vgat-ires-Cre ${ }^{+/-}$control female mice $(n=5$; Fig $4 F)$. Male Vgatires-Cre;Esr $1^{\text {lox/lox }}$ mice were found to kill female mates overnight $(n=3)$. 

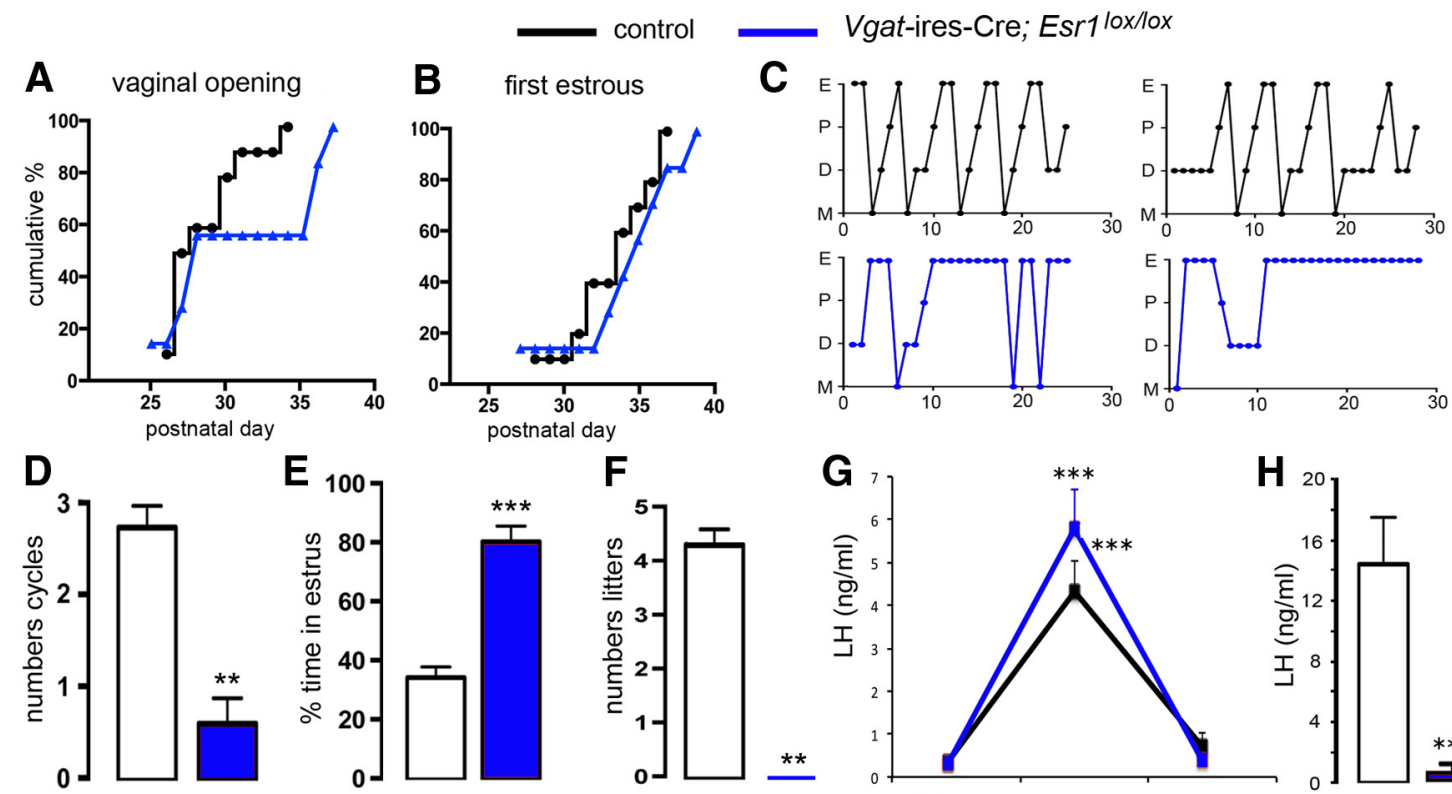

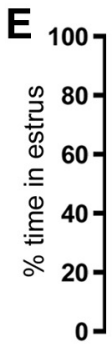

control
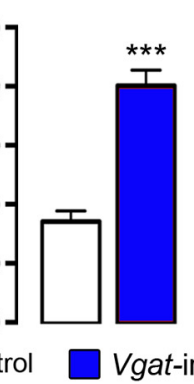

F

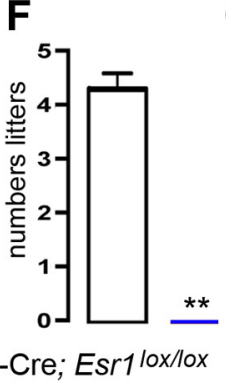

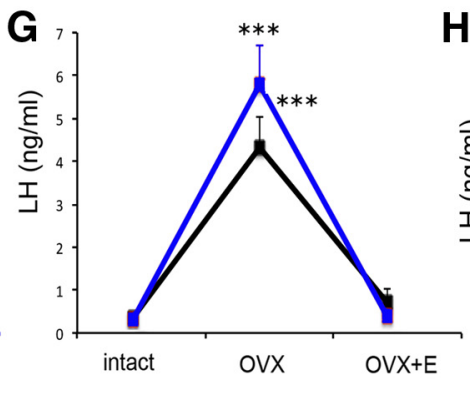

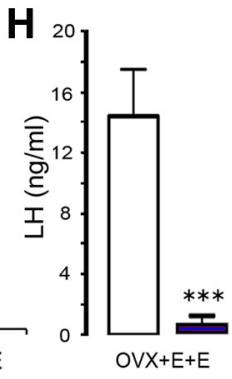

Figure 4. Reproductive profile of Vgat-ires-Cre;Esr $7^{\text {lox/lox }}$ mice. $\boldsymbol{A}, \boldsymbol{B}$, Puberty onset for control (black, $n=16$ ) and mutant (blue, $n=7$ ) mice displayed as cumulative percentage charts for vaginal opening $(\boldsymbol{A})$ and first estrous $(\boldsymbol{B})$. C, Representative adult estrous cycle profiles for two control (top) and two mutant (below) mice. $\boldsymbol{D}, \boldsymbol{E}$, Histograms showing the mean \pm SEM number of complete estrous cycles $(\boldsymbol{D})$ and percentage time spent in estrous $(\boldsymbol{E})$ in control $(n=20)$ and mutant Vgat-ires-Cre;Esr ${ }^{\text {lox/lox }}(n=9)$ mice. ${ }^{* *} p<0.01$, ${ }^{* * *} p<0.001($ Mann-Whitney $U$ tests). $\boldsymbol{F}$, Histogram showing the mean \pm SEM number of litters born to control $(n=5)$ and mutant $(n=5)$ female mice over a 3 month mating period. ${ }^{* *} p<0.01$ (Mann-Whitney $U$ tests). $\boldsymbol{G}$, Estrogen negative feedback in control (black, $n=7$ ) and mutant (blue, $n=6$ ) mice showing mean \pm SEM changes in LH secretion after OVX and OVX $+\mathrm{E}$. ${ }^{* * *} p<0.01$ versus intact and OVX $+\mathrm{E}$ (repeated-measures ANOVA with Bonferroni post hoc tests). $\boldsymbol{H}$, Positive feedback mean \pm SEM levels of LH in ovariectomized control $(n=7)$ and mutant $(n=6)$ mice treated with estradiol $(0 \mathrm{VX}+\mathrm{E}+\mathrm{E})$ to evoke the $\mathrm{GnRH} / \mathrm{LH}$ surge. ${ }^{* * *} p<0.001$ (Mann-Whitney $U$ test).

Basal LH levels were not different between Vgat-ires-Cre; Esr $1^{\text {lox/lox }}$ and Esr $1^{\text {lox/lox }}$ control mice (control $=0.33 \pm 0.08$ $\mathrm{ng} / \mathrm{ml}, n=7$; null $=0.30 \pm 0.03 \mathrm{ng} / \mathrm{ml}, n=6 ; U=18, p=0.69$, Mann-Whitney $U$ test). Experiments in which repeated blood samples were taken from intact, OVX, and OVX with estradiol replacement $(\mathrm{OVX}+\mathrm{E})$ mice revealed a normal estrogen negative feedback mechanism in Vgat-ires-Cre;Esr $1^{\text {lox/lox }}$ mice (Fig. 4G). There was no difference in the effects of OVX and $\mathrm{E} 2$ replacement in control and mutant mice (two-way repeated-measures ANOVA, group $\times$ treatment $\left.F_{(2,18)}=1.457, p=0.26\right)$. Control mice $(n=7)$ displayed the normal rise in LH secretion upon OVX ( $p<0.001$, Bonferroni post hoc test), with a return to basal levels after estradiol capsule implantation $(p<0.001$, Bonferroni post hoc test). Vgat-ires-Cre;Esr $1^{\text {lox/lox }}$ mice $(n=6)$ exhibited the same magnitude increase and then decrease in LH levels after OVX and estradiol replacement, respectively $(p<0.001$, Bonferroni post hoc test; Fig. $4 G$ ). In contrast, the estrogen positive feedback rise in LH was normal in control mice $(n=7)$, but absent in all Vgat-ires-Cre;Esr $1^{\text {lox/lox }}$ mice $(n=6$; Fig. $4 H ; U=0$, $p=0.0017$, Mann-Whitney $U$ test). Dual-labeled immunohistochemical analysis for cFos in GnRH neurons showed $52 \pm 6 \%$ of preoptic area GnRH neurons expressed cFos in controls $(n=8)$ compared with $0 \%$ in null mice ( $n=7$; data not shown). Deletion of ESR1 from GABAergic neurons results in the selective abolition of the estrogen positive feedback mechanism and infertility.

Deletion of Esr1 from Vglut2 neurons results in advanced puberty, abnormal estrogen feedback, disordered estrous cyclicity, and infertility in female mice

Vglut2-ires-Cre;Esr $1^{\text {lox/lox }}$ mice $(n=8)$ exhibited significantly advanced vaginal opening $(\mathrm{P} 23.9 \pm 0.8 ; U=11.50, p=0.0004$, Mann-Whitney $U$ test; Fig. $5 A)$ and first estrous $(\mathrm{P} 25.0 \pm 0.8$;
$U=7, p=0.0001$, Mann-Whitney test; Fig. $5 B$ ), with puberty onset occurring $\sim 5 \mathrm{~d}$ before controls $(n=16$; Fig. $5 A, B)$. As adults, control mice (Vglut2-ires-Cre and Esr ${ }^{\text {lox/lox }} ; n=20$ ) exhibited $3.1 \pm 0.2$ complete cycles of $6.9 \pm 0.4 \mathrm{~d}$ in duration, with $34 \pm 3 \%$ of the time spent in estrous (Fig. $5 C-E$ ). Vglut2-ires-Cre; Esr $1^{\text {lox/lox }}$ mice $(n=7)$ exhibited very disordered smears with no clear cycles $(0.1 \pm 0.1$ cycles; $U=1, p<0.0001$; Mann-Whitney $U$ test) and spent $83 \pm 7 \%$ of the time in estrous $(U=3, p<$ 0.0001; Mann-Whitney $U$ test; Fig. $5 C-E$ ). Fecundity studies revealed that Vglut2-Esr1-null female mice were infertile, with no litters born to mutant mice $(n=5)$ compared with $4.2 \pm 0.4$ litters/3 months to Vglut2-ires-Cre control female mice $(n=5$; Fig $5 F$ ). Vglut2-Esr1-null male mice generated a normal number of litters $(6.4 \pm 1.1$ vs $8.7 \pm 0.5$ controls; $U=3, p=0.171$, Mann-Whitney test) and pups/litter (3.25 \pm 0.25 vs $3.50 \pm 0.29$ controls; $U=6, p=0.99$, Mann-Whitney test) over the 3 month period.

Basal LH levels were significantly elevated in Vglut2-ires-Cre; Esr1 ${ }^{\text {lox } / \text { lox }}$ mice $(0.59 \pm 0.12 \mathrm{ng} / \mathrm{ml}, n=5)$ compared with Esr $1^{\text {lox/lox }}$ controls $(0.33 \pm 0.08 \mathrm{ng} / \mathrm{ml}, n=7 ; U=4.5, p=0.03$, Mann-Whitney $U$ test). Experiments in which repeated blood samples were taken from intact, OVX, and OVX+E mice revealed that estrogen negative feedback was abnormal in Vglut2ires-Cre; $E s r 1^{\text {lox/lox }}$ mice (Fig. 5G; two-way repeated-measures ANOVA, group $\times$ treatment $\left.F_{(2,18)}=15.294, p<0.001\right)$. Control mice $(n=7)$ displayed the normal rise in LH secretion upon OVX ( $p<0.001$, Bonferroni post hoc test), with a return to basal levels with estradiol capsule implantation $(p<0.001$, Bonferroni post hoc test). Vglut2-ires-Cre;Esr $1^{\text {lox/lox }}$ mice $(n=5)$ exhibited a nonsignificant ( $p=0.09$, Bonferroni post hoc test) trend for increased LH levels after OVX and no effect of estradiol replacement on LH concentrations (Fig. 5G). The estrogen positive 




Vglut2-ires-Cre; Esr1lox/lox
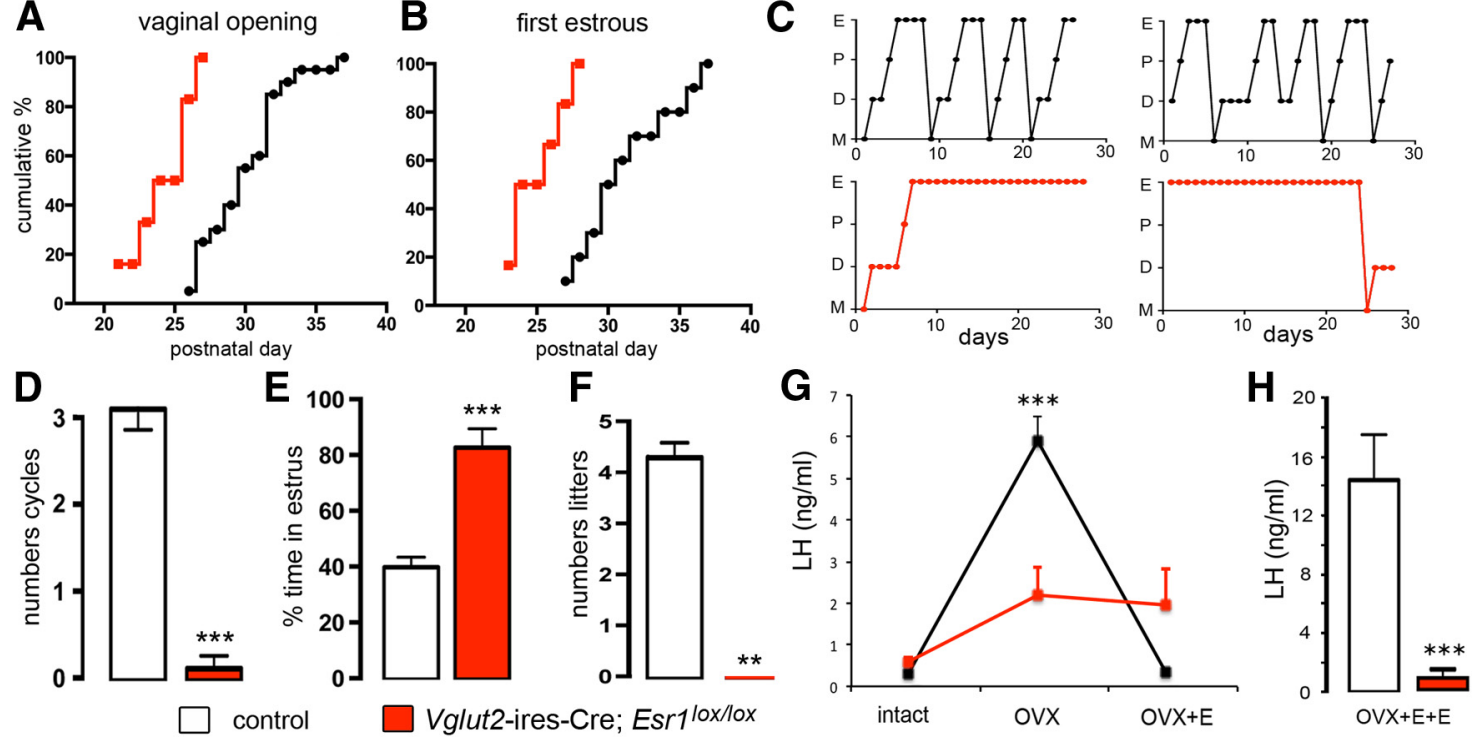

Figure 5. Reproductive profile of Vglut2-ires-Cre;Esr $7^{\text {lox/lox }}$ mice. $A, B$, Puberty onset for control (black, $n=16$ ) and mutant (red, $n=8$ ) mice displayed as cumulative percentage charts for vaginal opening $(\boldsymbol{A})$ and first estrous $(\boldsymbol{B})$. C, Representative adult estrous cycle profiles for two control (top) and two mutant (below) mice. $\boldsymbol{D}, \boldsymbol{E}$, Histograms showing the mean \pm SEM number of complete estrous cycles $(\boldsymbol{D})$ and percentage time spent in estrous $(\boldsymbol{E})$ in control $(n=20)$ and mutant Vglut2-ires-Cre; $E s r 1{ }^{\text {lox/lox }}(n=7)$ mice. ${ }^{* * *} p<0.001$ (Mann-Whitney $U$ tests). $\boldsymbol{F}$, Histogram showing the mean \pm SEM number of litters born to control $(n=5)$ and mutant $(n=5)$ female mice over a 3 month mating period. ${ }^{* *} p<0.01$ (Mann-Whitney $U$ tests). $\mathbf{G}$, Estrogen negative feedback in control (black, $n=7$ ) and mutant ( red, $n=5$ ) mice showing mean \pm SEM changes in LH secretion after OVX and $0 \mathrm{VX}+\mathrm{E}$. ${ }^{* * *} p<0.01$ versus intact and $0 \mathrm{VX}+\mathrm{E}($ repeated-measures ANOVA with Bonferroni post hoc tests). $\boldsymbol{H}$, Positive feedback mean \pm SEM levels of LH in ovariectomized control $(n=8)$ and mutant $(n=5)$ mice treated with estradiol $(0 V X+E+E)$ to evoke the GnRH/LH surge. ${ }^{* *} p<0.001$ (Mann-Whitney U test).

feedback mechanism was also examined, with all controls $(n=$ 11) but none of the Vglut2-Esr1-null mice $(n=5)$ exhibiting an LH surge (Fig. $5 H ; U=0, p=0.003$, Mann-Whitney test). Duallabel immunohistochemical analysis showed that $60 \pm 5 \%$ of preoptic area GnRH neurons expressed cFos in controls $(n=8)$ compared with $0 \%$ in null mice ( $n=5$; data not shown).

Unexpectedly, deletion of ESR1 from VGLUT2 glutamatergic neurons results in widespread defects in the neural control of fertility beginning at puberty that involves both negative and positive feedback mechanisms and results in infertility.

\section{Cre expression in kisspeptin neurons of Vgat- and Vglut2-} ires-Cre;Esr $1^{\text {lox/lox }}$ mice

Kisspeptin signaling in the brain is essential for puberty onset, estrogen feedback, and fertility in mice and humans (Seminara et al., 2003; de Roux et al., 2003; Dungan et al., 2007; d'Anglemont de Tassigny et al., 2007; Clarkson et al., 2008; Kirilov et al., 2013). Kisspeptin neurons expressing ESR1 are located principally in the AVPV and PVpo (referred to collectively as the RP3V) and ARN (Smith et al., 2006; Adachi et al., 2007) and there is evidence that subpopulations of these kisspeptin neurons may coexpress GABA and glutamate (Cravo et al., 2011). Therefore, it is possible that some of the reproductive abnormalities detected in Vgat/ Vglut2-ires-Cre;Esr $1^{\text {lox/lox }}$ mice might be derived from Cre expression in kisspeptin neurons with consequent deletion of ESR1. To investigate this possibility, we determined the numbers of kisspeptin neurons expressing Cre in Vgat- and Vglut2-ires-Cre mice. Neurons with Cre-immunoreactive nuclei were identified throughout the brain in a distribution similar to that found for tdTomato fluorescence. Dual-label immunohistochemistry for Cre and kisspeptin (Fig. $6 \mathrm{~A}$ ) revealed that $12 \pm 2 \%$ of RP3V and $68 \pm 5 \%$ of ARN kisspeptin neurons expressed VGLUT2 $(n=4$; Fig. $6 B$ ) compared with $22 \pm 5 \%$ of RP $3 \mathrm{~V}$ and $25 \pm 7 \%$ of ARN kisspeptin neurons expressing VGAT $(n=4$; Fig. $6 B)$.
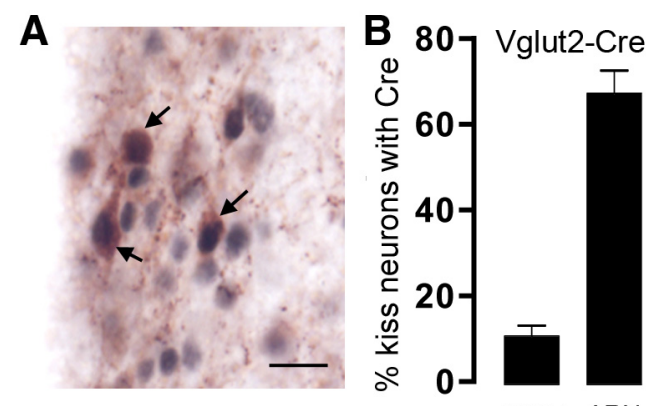

RP3V ARN

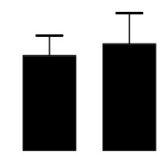

RP3V ARN

Figure 6. Expression of (re in kisspeptin neurons of Vgat- and Vglut2-Cre mouse lines. $\boldsymbol{A}$ Dual-label immunohistochemistry for (re (black nuclei) and kisspeptin (brown cytoplasm) in the AVPV of a Vglut2-ires-Cre mouse. Three dual-labeled cells are indicated with arrows. Scale bar, $20 \mu \mathrm{m}$. $\boldsymbol{B}$, Histograms showing the mean \pm SEM percentage of kisspeptin neurons expressing Cre in the RP3V and ARN of Vglut2-ires-Cre $(n=4)$ and Vgat-ires-Cre $(n=4)$ adult female diestrous mice.

\section{Discussion}

\section{Distribution of ESR1-expressing GABAergic and} glutamatergic neurons

We show here that subpopulations of ESR1-expressing cells in the hypothalamus and amygdala are GABAergic or glutamatergic, whereas those in the bed nucleus of the stria terminalis and hippocampus are GABAergic. The highest levels of ESR1-GABA coexpression were observed in the AVPV, ARN, and MEA, where $24-37 \%$ of all ESR1 cells were GABAergic. This compares with lower coexpression levels for glutamatergic neurons of $\sim 10$ $16 \%$ in these brain regions. Studies in the rat have demonstrated ESR1 in GABAergic and glutamatergic neurons in many of the same brain regions and at similar levels of coexpression (Flügge et al., 1986; Herbison, 1997; Eyigor et al., 2004; Kiss et al., 2013). Significant reductions in total ESR1 cell number were found in 
the AVPV, MPN, ARN, and MEA of Vgat-ires-Cre;Esr $1^{\text {lox/lox }}$, but not Vglut2-ires-Cre;Esr $1^{\text {lox/lox }}$, mice, reflecting the larger proportions of ESR1 neurons that are GABAergic compared with glutamatergic. Remarkably, the VMHvl exhibited a complete loss of ESR1 in Vglut2-ires-Cre;Esr $1^{\text {lox/lox }}$ mice, indicating that all ESR1 neurons in the VMHvl express Vglut2 at some point in development. Studies in the adult rat have reported that $20-80 \%$ of ESR 1 cells in the VMHvl express Vglut2 mRNA (Eyigor et al., 2004; Kiss et al., 2013).

\section{ESR-1-dependent GABAergic function in the GnRH neuronal network}

There is substantial evidence for a role of estradiol-modulated GABAergic transmission in both the negative and positive feedback mechanisms of rodents (Levine, 2014; Herbison, 2015). This rests principally on the finding that many aspects of GABA transmission are modulated by estradiol in the vicinity of the GnRH neuron cell bodies (Herbison, 1997) and that GABA concentrations in this region are elevated at times of negative feedback (Herbison et al., 1991), but then fall just before the GnRH/LH surge (Robinson et al., 1991; Jarry et al., 1992; TinTin-Win-Shwe et al., 2004). This has led to the hypothesis that estradiol modulates GABAergic signaling to suppress GnRH neuron activity and help bring about negative feedback (Herbison, 1998; Petersen et al., 2003). However, the present observations fail to support this mechanism as being critical for estrogen negative feedback because it was normal in Vgat-ires-Cre;Es $r 1^{\text {lox/lox }}$ mice. It is possible that compensatory mechanisms or ESR2 (Cheong et al., 2014) may have replaced the need for ESR1-GABA neurons in Vgat-ires-Cre;Esr $1^{\text {lox/lox }}$ mice. Mice with a GnRH neuron-selective reduction in $\mathrm{GABA}_{\mathrm{A}}$ receptor signaling exhibit a patent but abnormally sensitive negative feedback mechanism (Lee et al., 2010). Nevertheless, against expectations and unlike our observations for glutamate neurons, we show that ESR1 in GABA neurons is not essential for negative feedback.

A fall in GABA concentrations before the surge appears critical for positive feedback (Herbison and Dyer, 1991; Kimura and Jinnai, 1994). How and where this affects GnRH neurons has been difficult to ascertain. Electrophysiological studies have shown that, although $\mathrm{GABA}_{\mathrm{B}}$ activation is robustly inhibitory (Zhang et al., 2009; Liu and Herbison, 2011), GABA receptors can excite GnRH neurons (Herbison and Moenter, 2011), even in adults in vivo (Constantin et al., 2013). Whereas a subpopulation of $\mathrm{GnRH}$ neurons in daily surging mice exhibit enhanced $\mathrm{GABA}_{\mathrm{A}}$ receptor postsynaptic potentials at the time of positive feedback (Christian and Moenter, 2007), studies in the rat show reduced numbers of VGAT appositions on GnRH neurons at the this time (Ottem et al., 2004). Therefore, it remains uncertain how GABA affects GnRH neurons at the time of positive feedback. Nevertheless, the present study clearly demonstrates that ESR1 in GABA neurons is critical for estrogen positive feedback.

We speculate that the key estradiol-modulated GABA neurons are located in the $\mathrm{RP} 3 \mathrm{~V}$, the locus of estradiol action for positive feedback (Herbison, 2008). RP3V GABA neurons express ESR1 and project directly to GnRH neurons signaling through both $\mathrm{GABA}_{\mathrm{A}}$ (Liu et al., 2011) and $\mathrm{GABA}_{\mathrm{B}}$ (Liu and Herbison, 2011) receptors (Fig. 7). We find that $\sim 20 \%$ of RP3V kisspeptin neurons express Cre in Vgat-ires-Cre mice, indicating that a small subpopulation of kisspeptin neurons lose ESR1 expression in these mice. However, this is unlikely to have any impact upon the positive feedback mechanism as mice with only $50 \%$ of their RP3V kisspeptin neurons are still able to exhibit positive feedback (Szymanski and Bakker, 2012).



Figure 7. Schematic diagram summarizing the likely essential roles of ESR1-expressing GABA (blue) and glutamate (red) neurons in the various estrogen feedback mechanisms within the GnRH neuronal network. The possible locations of the cell bodies of the respective GABA and glutamate inputs within each feedback loop are indicated within each gray box. KNDy, Kisspeptin-Neurokinin B-Dynoprhin neuron.

\section{ESR-1-dependent glutamatergic function in the GnRH neuronal network}

Although glutamatergic transmission is important for $\mathrm{GnRH}$ neuronal network integrity (Brann, 1995; Iremonger et al., 2010), compared with GABA, it has received relatively little investigation with respect to estrogen feedback (Levine, 2014; Herbison, 2015). For positive feedback, an increase in glutamate levels in the vicinity of the GnRH neuron cell bodies occurs at the time of the GnRH/LH surge (Ping et al., 1994; Jarry et al., 1995) and glutamate receptor antagonists abolish the surge (Brann and Mahesh, 1991; Ping et al., 1997). We provide here the first demonstration that ESR1 in glutamate neurons is essential for positive feedback. As noted above for GABA, we suspect that estradiol modulates VGLUT2 neurons independently of kisspeptin to help bring about positive feedback because only $12 \%$ of RP3V kisspeptin neurons are targeted in Vglut2-ires-Cre mice. Similarly, we speculate that the key glutamatergic neurons involved in this mechanism are located in the RP3V, where they express ESR1 and are known to project to GnRH neurons activating predominantly AMPA receptors (Liu et al., 2011; Fig. 7). Interestingly, many ESR1-expressing neurons in the preoptic area of the rat coexpress GABA and glutamate (Ottem et al., 2004) and it remains to be determined whether this also occurs in the mouse.

In rodents, $\mathrm{GnRH}$ neuron activity is restrained after birth by the suppressive influence of estradiol, which gradually wanes to enable increased LH pulsatility and puberty onset (Goodman, 2014; Prevot, 2014). We find here that ESR1-modulated glutamate transmission is a critical component of this restraint mechanism. This was unexpected because, although glutamate neurons are involved in the pubertal activation of GnRH neurons, their estradiol sensitivity had not been considered previously (Clarkson and Herbison, 2006; Prevot, 2014). Further, most attention had been focused upon GABAergic neurons, yet we find normal puberty onset in Vgat-ires-Cre;Esr $1^{\text {lox/lox }}$ mice. Further, the permissive actions of leptin on puberty onset depend upon GABAergic and not glutamatergic neurons (Zuure et al., 2013; Martin et al., 2014).

We noted that the $\sim 5 \mathrm{~d}$ advance in puberty onset of Vglut2ires-Cre;Esr $1^{\text {lox/lox }}$ mice was similar in direction, but not magnitude, to that of kisspeptin-Esr 1 knock-out mice, which exhibit an 
$\sim 10 \mathrm{~d}$ advance in puberty onset with no first estrous (Mayer et al., 2010). Because the majority of ARN kisspeptin neurons express Cre in Vglut2-ires-Cre;Esr $1^{\text {lox/lox }}$ mice, it is possible that their early pubertal onset arises in part from deletion of ESR1 in ARN neurons coexpressing glutamate and kisspeptin. These kisspeptin cells, also known as Kisspeptin-Neurokinin B-Dynorphin (KNDy) neurons (Goodman et al., 2007), make direct connections with GnRH neurons before birth (Kumar et al., 2014) and likely target the distal dendronic and terminal processes of $\mathrm{GnRH}$ neurons (Yip et al., 2015). Glutamate and kisspeptin can stimulate these processes directly (Herde et al., 2013; Glanowska and Moenter, 2015) and the synchronized activation of GnRH neuron projections can generate pulses of LH secretion (Campos and Herbison, 2014). Therefore, it is possible that the deletion of ESR1 in ARN KNDy or glutamate neurons results in estradiol being unable to restrain their activity in the late prepubertal period, resulting in precocious kisspeptin and/or glutamate activation of episodic GnRH secretion and consequent early puberty.

We also show that ESR1-expressing glutamate neurons are essential for the negative feedback mechanism. Because ESR1 in the ARN is essential for negative feedback in female mice (Yeo and Herbison, 2014), it is possible that this involves ARN ESR1glutamate neurons. In this case, however, the ARN glutamatergic cell population is unlikely to coexpress kisspeptin because negative feedback remains patent after deletion of Esr1 in kisspeptin neurons (Dubois et al., 2015). Therefore, one part of the multicomponent negative feedback mechanism (Herbison, 1998) may be an ESR1-dependent suppression of an ARN excitatory glutamatergic input to $\mathrm{GnRH}$ neurons (Fig. 7). Indeed, the frequency of AMPA postsynaptic potentials in GnRH neurons is reduced at the time of negative feedback in daily surging mice (Christian et al., 2009).

It is important to note that ESR1-expressing VGLUT2 neurons in brain regions outside the ARN and AVPV may also be involved. Although ESR1 cells in the VMHvl are not part of the GnRH neuronal network (Herbison, 2015), they are nevertheless essential for reproductive behavior (Musatov et al., 2006; Lee et al., 2014). Therefore, beyond the failure to ovulate, the absence of ESR1 in the VMHvl of Vglut2-ires-Cre;Esr $1^{\text {lox/lox }}$ mice would likely abolish lordosis behavior and compound further their infertility. VMHvl-ESR1 cells are also implicated in metabolic control (Xu et al., 2011; Martínez de Morentin et al., 2014) and this may indirectly affect fertility. It is also important to consider recent evidence in the rat that both GABA and glutamate signaling in the MEApd can modulate puberty onset (Li et al., 2015). Therefore, deletion of ESR1 from GABA and glutamate neurons in the amygdala may also contribute to the reproductive phenotype of these mice.

In summary, we report that the deletion of ESR1 from GABA neurons results in defective positive feedback with normal puberty onset and negative feedback. In contrast, deletion of ESR1 from VGLUT2 neurons produces multiple dysfunctional estradiol feedback loops. These new observations highlight the importance of ESR1-dependent modulation of glutamatergic neurons within the GnRH neuronal network for fertility.

\section{References}

Adachi S, Yamada S, Takatsu Y, Matsui H, Kinoshita M, Takase K, Sugiura H, Ohtaki T, Matsumoto H, Uenoyama Y, Tsukamura H, Inoue K, Maeda K (2007) Involvement of anteroventral periventricular metastin/kisspeptin neurons in estrogen positive feedback action on luteinizing hormone release in female rats. J Reprod Dev 53:367-378. CrossRef Medline
Brann DW (1995) Glutamate: a major excitatory transmitter in neuroendocrine regulation. Neuroendocrinology 61:213-225. CrossRef Medline

Brann DW, Mahesh VB (1991) Endogenous excitatory amino acid involvement in the preovulatory and steroid-induced surge of gonadotropins in the female rat. Endocrinology 128:1541-1547. CrossRef Medline

Campos P, Herbison AE (2014) Optogenetic activation of GnRH neurons reveals minimal requirements for pulsatile luteinizing hormone secretion. Proc Natl Acad Sci U S A 111:18387-18392. CrossRef Medline

Casanova E, Fehsenfeld S, Mantamadiotis T, Lemberger T, Greiner E, Stewart AF, Schütz G (2001) A CamKIIalpha iCre BAC allows brain-specific gene inactivation. Genesis 31:37-42. CrossRef Medline

Cheong RY, Porteous R, Chambon P, Abrahám I, Herbison AE (2014) Effects of neuron-specific estrogen receptor (ER) alpha and ERbeta deletion on the acute estrogen negative feedback mechanism in adult female mice. Endocrinology 155:1418-1427. CrossRef Medline

Christian CA, Moenter SM (2007) Estradiol induces diurnal shifts in GABA transmission to gonadotropin-releasing hormone neurons to provide a neural signal for ovulation. J Neurosci 27:1913-1921. CrossRef Medline

Christian CA, Pielecka-Fortuna J, Moenter SM (2009) Estradiol suppresses glutamatergic transmission to gonadotropin-releasing hormone neurons in a model of negative feedback in mice. Biol Reprod 80:1128-1135. CrossRef Medline

Clarkson J, Herbison AE (2006) Development of GABA and glutamate signaling at the GnRH neuron in relation to puberty. Mol Cell Endocrinol 254- 255:32-38. Medline

Clarkson J, Herbison AE (2009) Oestrogen, kisspeptin, GPR54 and the preovulatory luteinising hormone surge. J Neuroendocrinol 21:305-311. CrossRef Medline

Clarkson J, d'Anglemont de Tassigny X, Moreno AS, Colledge WH, Herbison AE (2008) Kisspeptin-GPR54 signaling is essential for preovulatory gonadotropin-releasing hormone neuron activation and the luteinizing hormone surge. J Neurosci 28:8691-8697. CrossRef Medline

Clarkson J, d'Anglemont de Tassigny X, Colledge WH, Caraty A, Herbison AE (2009) Distribution of kisspeptin neurones in the adult female mouse brain. J Neuroendocrinol 21:673-682. CrossRef Medline

Constantin S, Iremonger KJ, Herbison AE (2013) In vivo recordings of GnRH neuron firing reveal heterogeneity and dependence upon GABAA receptor signaling. J Neurosci 33:9394-9401. CrossRef Medline

Couse JF, Yates MM, Walker VR, Korach KS (2003) Characterization of the hypothalamic-pituitary-gonadal (HPG) axis in estrogen receptor null mice reveals hypergonadism and endocrine sex-reversal in females lacking ER $\alpha$ but not ER $\beta$. Mol Endocrinol 17:1039-1053. CrossRef Medline

Cravo RM, Margatho LO, Osborne-Lawrence S, Donato J Jr, Atkin S, Bookout AL, Rovinsky S, Frazão R, Lee CE, Gautron L, Zigman JM, Elias CF (2011) Characterization of Kiss1 neurons using transgenic mouse models. Neuroscience 173:37-56. CrossRef Medline

d'Anglemont de Tassigny X, Fagg LA, Dixon JP, Day K, Leitch HG, Hendrick AG, Zahn D, Franceschini I, Caraty A, Carlton MB, Aparicio SA, Colledge WH (2007) Hypogonadotropic hypogonadism in mice lacking a functional Kiss1 gene. Proc Natl Acad Sci U S A 104:10714-10719. CrossRef Medline

de Croft S, Piet R, Mayer C, Mai O, Boehm U, Herbison AE (2012) Spontaneous kisspeptin neuron firing in the adult mouse reveals marked sex and brain region differences but no support for a direct role in negative feedback. Endocrinology 153:5384-5393. CrossRef Medline

de Roux N, Genin E, Carel JC, Matsuda F, Chaussain JL, Milgrom E (2003) Hypogonadotropic hypogonadism due to loss of function of the KiSS1derived peptide receptor GPR54. Proc Natl Acad Sci U S A 100:1097210976. CrossRef Medline

Dubois SL, Acosta-Martínez M, DeJoseph MR, Wolfe A, Radovick S, Boehm U, Urban JH, Levine JE (2015) Positive, but not negative feedback actions of estradiol in adult female mice require estrogen receptor alpha in kisspeptin neurons. Endocrinology 156:1111-1120. CrossRef Medline

Dungan HM, Gottsch ML, Zeng H, Gragerov A, Bergmann JE, Vassilatis DK, Clifton DK, Steiner RA (2007) The role of kisspeptin-GPR54 signaling in the tonic regulation and surge release of gonadotropin-releasing hormone/luteinizing hormone. J Neurosci 27:12088-12095. CrossRef Medline

Eyigor O, Lin W, Jennes L (2004) Identification of neurones in the female rat hypothalamus that express oestrogen receptor-alpha and vesicular glutamate transporter-2. J Neuroendocrinol 16:26-31. CrossRef Medline Flügge G, Oertel WH, Wuttke W (1986) Evidence for estrogen-receptive 
GABAergic neurons in the preoptic/anterior hypothalamic area of the rat brain. Neuroendocrinology 43:1-5. CrossRef Medline

Foster AC, Kemp JA (2006) Glutamate- and GABA-based CNS therapeutics. Curr Opin Pharmacol 6:7-17. CrossRef Medline

Franklin KBJ, Paxinos G (1997) The mouse brain in stereotaxic coordinates. San Diego: Academic.

Glanowska KM, Moenter SM (2015) Differential regulation of GnRH secretion in the preoptic area (POA) and the median eminence (ME) in male mice. Endocrinology 156:231-241. CrossRef Medline

Glidewell-Kenney C, Hurley LA, Pfaff L, Weiss J, Levine JE, Jameson JL (2007) Nonclassical estrogen receptor alpha signaling mediates negative feedback in the female mouse reproductive axis. Proc Natl Acad Sci U S A 104:8173-8177. CrossRef Medline

Goodman RL (2014) Neuroendocrine control of goandotropin secretion: comparative aspects. In: Knobil and Neill's physiology of reproduction, Ed 4 (Plant TM, Zeleznik AJ, eds), pp 1537-1574. San Diego: Academic.

Goodman RL, Lehman MN, Smith JT, Coolen LM, de Oliveira CV, Jafarzadehshirazi MR, Pereira A, Iqbal J, Caraty A, Ciofi P, Clarke IJ (2007) Kisspeptin neurons in the arcuate nucleus of the ewe express both dynorphin A and neurokinin B. Endocrinology 148:5752-5760. CrossRef Medline

Herbison AE (1997) Estrogen regulation of GABA transmission in rat preoptic area. Brain Res Bull 44:321-326. CrossRef Medline

Herbison AE (1998) Multimodal influence of estrogen upon gonadotropinreleasing hormone neurons. Endocr Rev 19:302-330. CrossRef Medline

Herbison AE (2008) Estrogen positive feedback to gonadotropin-releasing hormone $(\mathrm{GnRH})$ neurons in the rodent: the case for the rostral periventricular area of the third ventricle (RP3V). Brain Res Rev 57:277-287. CrossRef Medline

Herbison AE (2015) Physiology of the adult GnRH neuronal network. In: Knobil and Neill's physiology of reproduction, Ed 4 (Plant TM, Zeleznik AJ, eds), pp 399-467. San Diego: Academic.

Herbison AE, Dyer RG (1991) Effect on luteinizing hormone secretion of GABA receptor modulation in the medial preoptic area at the time of proestrous luteinizing hormone surge. Neuroendocrinology 53:317-320. CrossRef Medline

Herbison AE, Moenter SM (2011) Depolarising and hyperpolarising actions of $\mathrm{GABA}(\mathrm{A})$ receptor activation on gonadotrophin-releasing hormone neurones: towards an emerging consensus. J Neuroendocrinol 23:557569. CrossRef Medline

Herbison AE, Pape JR (2001) New evidence for estrogen receptors in gonadotropin-releasing hormone neurons. Front Neuroendocrinol 22: 292-308. CrossRef Medline

Herbison AE, Heavens RP, Dye S, Dyer RG (1991) Acute action of oestrogen on medial preoptic gamma-aminobutyric acid neurons: correlation with oestrogen negative feedback on luteinizing hormone secretion. J Neuroendocrinol 3:101-106. CrossRef Medline

Herde MK, Iremonger KJ, Constantin S, Herbison AE (2013) GnRH neurons elaborate a long-range projection with shared axonal and dendritic functions. J Neurosci 33:12689-12697. CrossRef Medline

Iremonger KJ, Constantin S, Liu X, Herbison AE (2010) Glutamate regulation of GnRH neuron excitability. Brain Res 1364:35-43. CrossRef Medline

Jarry H, Hirsch B, Leonhardt S, Wuttke W (1992) Amino acid neurotransmitter release in the preoptic area of rats during the positive feedback actions of estradiol on LH release. Neuroendocrinology 56:133-140. CrossRef Medline

Jarry H, Leonhardt S, Schwarze T, Wuttke W (1995) Preoptic rather than mediobasal hypothalamic amino acid neurotransmitter release regulates GnRH secretion during the estrogen-induced LH surge in the ovariectomized rat. Neuroendocrinology 62:479-486. CrossRef Medline

Kalra SP (1993) Mandatory neuropeptide-steroid signaling for the preovulatory luteinizing hormone-releasing hormone discharge. Endocr Rev 14: 507-538. Medline

Khan AR, Kauffman AS (2012) The role of kisspeptin and RFamide-related peptide-3 neurones in the circadian-timed preovulatory luteinising hormone surge. J Neuroendocrinol 24:131-143. CrossRef Medline

Kimura F, Jinnai K (1994) Bicuculline infusions advance the timing of luteinizing hormone surge in progestrous rats: comparisons with naloxone effects. Horm Behav 28:424-430. CrossRef Medline

Kirilov M, Clarkson J, Liu X, Roa J, Campos P, Porteous R, Schütz G, Herbi- son AE (2013) Dependence of fertility on kisspeptin-Gpr54 signaling at the GnRH neuron. Nat Commun 4:2492. Medline

Kiss J, Csaba Z, Csáki A, Halász B (2013) Demonstration of estrogen receptor alpha protein in glutamatergic (vesicular glutamate transporter $2 \mathrm{im}$ munoreactive) neurons of the female rat hypothalamus and amygdala using double-label immunocytochemistry. Exp Brain Res 226:595-602. CrossRef Medline

Kordon C, Drouva SV, Martinez de la Escalera G, Weiner RI (1994) Role of classic and peptide neuromodulators in the neuroendocrine regulation of luteinizing hormone and prolactin. In: The physiology of reproduction, Ed 2 (Knobil E, Neill JD, eds), pp 1621-1681. New York: Raven.

Kumar D, Freese M, Drexler D, Hermans-Borgmeyer I, Marquardt A, Boehm U (2014) Murine arcuate nucleus kisspeptin neurons communicate with GnRH neurons in utero. J Neurosci 34:3756-3766. CrossRef Medline

Lee H, Kim DW, Remedios R, Anthony TE, Chang A, Madisen L, Zeng H, Anderson DJ (2014) Scalable control of mounting and attack by Esr 1+ neurons in the ventromedial hypothalamus. Nature 509:627-632. CrossRef Medline

Lee K, Porteous R, Campbell RE, Lüscher B, Herbison AE (2010) Knockdown of GABA(A) receptor signaling in GnRH neurons has minimal effects upon fertility. Endocrinology 151:4428-4436. CrossRef Medline

Levine JE (2014) Neuroendocrine control of the ovarian cycle of the rat. In: Knobli and Neill's physiology or reproduction, Ed 4 (Plant TM, Zeleznik AJ, eds), pp 1199-1258. San Diego: Academic.

Li XF, Hu MH, Hanley BP, Lin YS, Poston L, Lightman SL, O’Byrne KT (2015) The posterodorsal medial amygdala regulates the timing of puberty onset in female rats. Endocrinology 156:3725-3736. CrossRef Medline

Liu X, Herbison AE (2011) Estrous cycle- and sex-dependent changes in pre- and postsynaptic GABAB control of GnRH neuron excitability. Endocrinology 152:4856-4864. CrossRef Medline

Liu X, Porteous R, d'Anglemont de Tassigny X, Colledge WH, Millar R, Petersen SL, Herbison AE (2011) Frequency-dependent recruitment of fast amino acid and slow neuropeptide neurotransmitter release controls gonadotropin-releasing hormone neuron excitability. J Neurosci 31: 2421-2430. CrossRef Medline

Madisen L, Zwingman TA, Sunkin SM, Oh SW, Zariwala HA, Gu H, Ng LL, Palmiter RD, Hawrylycz MJ, Jones AR, Lein ES, Zeng H (2010) A robust and high-throughput Cre reporting and characterization system for the whole mouse brain. Nat Neurosci 13:133-140. CrossRef Medline

Martin C, Navarro VM, Simavli S, Vong L, Carroll RS, Lowell BB, Kaiser UB (2014) Leptin-responsive GABAergic neurons regulate fertility through pathways that result in reduced kisspeptinergic tone. J Neurosci 34:60476056. CrossRef Medline

Martínez de Morentin PB, González-García I, Martins L, Lage R, FernándezMallo D, Martínez-Sánchez N, Ruíz-Pino F, Liu J, Morgan DA, Pinilla L, Gallego R, Saha AK, Kalsbeek A, Fliers E, Bisschop PH, Diéguez C, Nogueiras R, Rahmouni K, Tena-Sempere M, López M (2014) Estradiol regulates brown adipose tissue thermogenesis via hypothalamic AMPK. Cell Metab 20:41-53. CrossRef Medline

Mayer C, Acosta-Martinez M, Dubois SL, Wolfe A, Radovick S, Boehm U, Levine JE (2010) Timing and completion of puberty in female mice depend on estrogen receptor alpha-signaling in kisspeptin neurons. Proc Natl Acad Sci U S A 107:22693-22698. CrossRef Medline

Mitra SW, Hoskin E, Yudkovitz J, Pear L, Wilkinson HA, Hayashi S, Pfaff DW, Ogawa S, Rohrer SP, Schaeffer JM, McEwen BS, Alves SE (2003) Immunolocalization of estrogen receptor beta in the mouse brain: comparison with estrogen receptor alpha. Endocrinology 144:2055-2067. CrossRef Medline

Moenter SM, Chu Z, Christian CA (2009) Neurobiological mechanisms underlying oestradiol negative and positive feedback regulation of gonadotrophin-releasing hormone neurones. J Neuroendocrinol 21:327333. CrossRef Medline

Musatov S, Chen W, Pfaff DW, Kaplitt MG, Ogawa S (2006) RNAimediated silencing of estrogen receptor $\{$ alpha $\}$ in the ventromedial nucleus of hypothalamus abolishes female sexual behaviors. Proc Natl Acad Sci U S A 103:10456-10460. CrossRef Medline

Ohkura S, Uenoyama Y, Yamada S, Homma T, Takase K, Inoue N, Maeda K, Tsukamura H (2009) Physiological role of metastin/kisspeptin in regulating gonadotropin-releasing hormone $(\mathrm{GnRH})$ secretion in female rats. Peptides 30:49-56. CrossRef Medline 
Ottem EN, Godwin JG, Krishnan S, Petersen SL (2004) Dual-phenotype GABA/glutamate neurons in adult preoptic area: sexual dimorphism and function. J Neurosci 24:8097-8105. CrossRef Medline

Petersen SL, Ottem EN, Carpenter CD (2003) Direct and indirect regulation of gonadotropin-releasing hormone neurons by estradiol. Biol Reprod 69:1771-1778. CrossRef Medline

Ping L, Mahesh VB, Wiedmeier VT, Brann DW (1994) Release of glutamate and aspartate from the preoptic area during the progesterone-induced LH surge: in vivo microdialysis studies. Neuroendocrinology 59:318-324. CrossRef Medline

Ping L, Mahesh VB, Bhat GK, Brann DW (1997) Regulation of gonadotropin-releasing hormone and luteinizing hormone secretion by AMPA receptors: evidence for a physiological role of AMPA receptors in the steroid-induced luteinizing hormone surge. Neuroendocrinology 66: 246-253. CrossRef Medline

Prevot V (2014) Puberty in mice and rats. In: Knobil and Neill's physiology of reproduction, Ed 4 (Plant TM, Zeleznik AJ, eds), pp 1395-1439. San Diego: Academic.

Prevot V, Hanchate NK, Bellefontaine N, Sharif A, Parkash J, Estrella C, Allet C, de Seranno S, Campagne C, de Tassigny Xd, Baroncini M (2010) Function-related structural plasticity of the GnRH system: a role for neuronal-glial-endothelial interactions. Front Neuroendocrinol 31:241258. CrossRef Medline

Robinson JE, Kendrick KM, Lambart CE (1991) Changes in the release of gamma-aminobutyric acid and catecholamines in the preoptic/septal area prior to and during the preovulatory surge of luteinizing hormone in the ewe. J Neuroendocrinol 3:393-399. CrossRef Medline

Seminara SB, Messager S, Chatzidaki EE, Thresher RR, Acierno JS Jr, Shagoury JK, Bo-Abbas Y, Kuohung W, Schwinof KM, Hendrick AG, Zahn D, Dixon J, Kaiser UB, Slaugenhaupt SA, Gusella JF, O'Rahilly S, Carlton MB, Crowley WF Jr, Aparicio SA, Colledge WH (2003) The GPR54 gene as a regulator of puberty. $\mathrm{N}$ Engl J Med 349:1614-1627. CrossRef Medline

Smith JT (2013) Sex steroid regulation of kisspeptin circuits. Adv Exp Med Biol 784:275-295. CrossRef Medline

Smith JT, Popa SM, Clifton DK, Hoffman GE, Steiner RA (2006) Kiss1 neurons in the forebrain as central processors for generating the preovulatory luteinizing hormone surge. J Neurosci 26:6687-6694. CrossRef Medline

Szymanski L, Bakker J (2012) Aromatase knock-out mice show normal steroid-induced activation of gonadotrophin-releasing hormone neu- rones and luteinising hormone surges with a reduced population of kisspeptin neurones in the rostral hypothalamus. J Neuroendocrinol 24: 1222-1233. CrossRef Medline

Takamori S (2006) VGLUTs: 'exciting' times for glutamatergic research? Neurosci Res 55:343-351. CrossRef Medline

Tin-Tin-Win-Shwe, Mitsushima D, Shinohara K, Kimura F (2004) Sexual dimorphism of GABA release in the medial preoptic area and luteinizing hormone release in gonadectomized estrogen-primed rats. Neuroscience 127:243-250. CrossRef Medline

Vong L, Ye C, Yang Z, Choi B, Chua S Jr, Lowell BB (2011) Leptin action on GABAergic neurons prevents obesity and reduces inhibitory tone to POMC neurons. Neuron 71:142-154. CrossRef Medline

Wintermantel TM, Campbell RE, Porteous R, Bock D, Gröne HJ, Todman MG, Korach KS, Greiner E, Perez CA, Schütz G, Herbison AE (2006) Definition of estrogen receptor pathway critical for estrogen positive feedback to gonadotropin-releasing hormone neurons and fertility. Neuron 52:271-280. CrossRef Medline

Wojcik SM, Katsurabayashi S, Guillemin I, Friauf E, Rosenmund C, Brose N, Rhee JS (2006) A shared vesicular carrier allows synaptic corelease of GABA and glycine. Neuron 50:575-587. CrossRef Medline

Xu Y, Nedungadi TP, Zhu L, Sobhani N, Irani BG, Davis KE, Zhang X, Zou F, Gent LM, Hahner LD, Khan SA, Elias CF, Elmquist JK, Clegg DJ (2011) Distinct hypothalamic neurons mediate estrogenic effects on energy homeostasis and reproduction. Cell Metab 14:453-465. CrossRef Medline

Yeo SH, Herbison AE (2014) Estrogen-negative feedback and estrous cyclicity are critically dependent upon estrogen receptor-alpha expression in the arcuate nucleus of adult female mice. Endocrinology 155:2986-2995. CrossRef Medline

Yip SH, Boehm U, Herbison AE, Campbell RE (2015) Conditional viral tract tracing delineates the projections of the distinct kisspeptin neuron populations to GnRH neurons in the mouse. Endocrinology 156:25822594. CrossRef Medline

Zhang C, Bosch MA, Rønnekleiv OK, Kelly MJ (2009) Gamma-aminobutyric acid B receptor mediated inhibition of gonadotropin-releasing hormone neurons is suppressed by kisspeptin-G protein-coupled receptor 54 signaling. Endocrinology 150:2388-2394. CrossRef Medline

Zuure WA, Roberts AL, Quennell JH, Anderson GM (2013) Leptin signaling in GABA Neurons, but not glutamate neurons, is required for reproductive function. J Neurosci 33:17874-17883. CrossRef Medline 